\title{
Bringing Women Entrepreneurs In Policy Focus For SME Development In Bangladesh
}

\author{
Rita Afsar \\ Bangladesh Institute of Development Studies
}

\begin{abstract}
Small and medium enterprises (SMEs) are often considered as panacea for generating labour-intensive employment opportunities needed to absorb expanding labour force, providing much needed flexibility and innovations in the economy as a whole, diversifying economic activities and making significant contribution to export and poverty alleviation. There is disproportionately high concentration of women in the low-productive, low-income generating micro-enterprises and subsequent low representation of women entrepreneurs in the SME sector due to some of the inherent problems of this sector compounded with systematic gender based inequality. Data from the Bangladesh Bureau of Statistics show that in Bangladesh, only about 7.4 per cent of the establishments in manufacturing and services as of 2001-2003 are owned by women. This compares with about 20 per cent in India as of 2000 and that of nearly 39 per cent in the South-East Asian region. Clearly it suggests the need for policy push to increase women's participation and enhance their capacity. Based on a thorough literature review including research and other policy as well as programme related documents, this paper highlights the major constraints faced by women entrepreneurs and suggest appropriate policy measures to address those gaps and challenges from a review of the existing SME policies. It argues that the whole process of SME development should have a clear structure and a vision for enhancing capability of the entrepreneurs to compete in the global and domestic markets which demand special focus on women entrepreneurs who are often marginalized in the existing women unfriendly environment. A broad and comprehensive focus on information and capital accessibility, skill development and marketing linkage is essential to increase women's participation in SME.
\end{abstract}

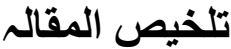

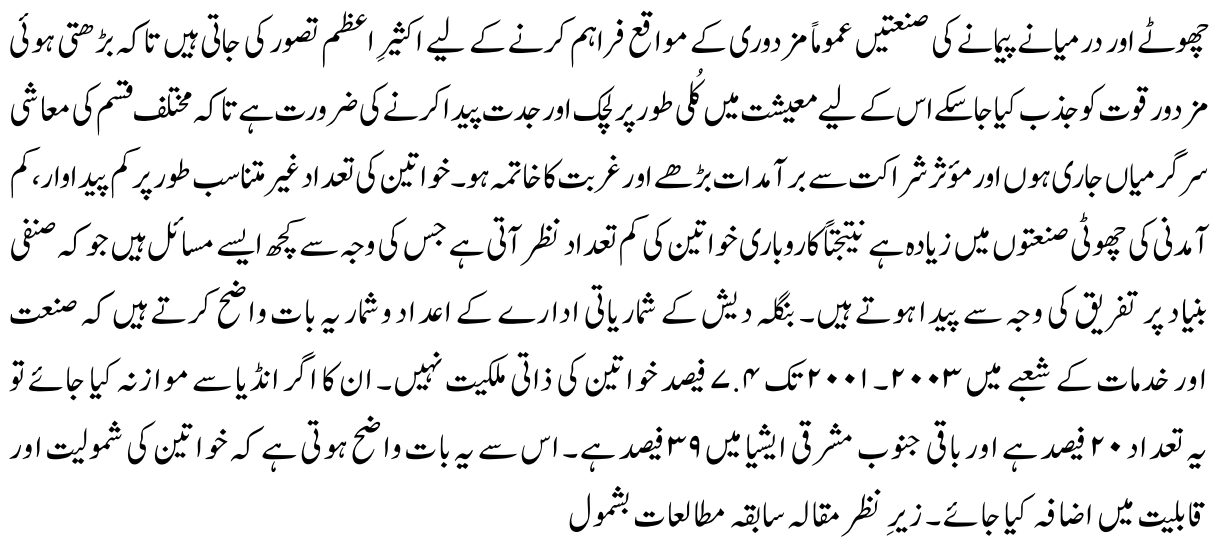




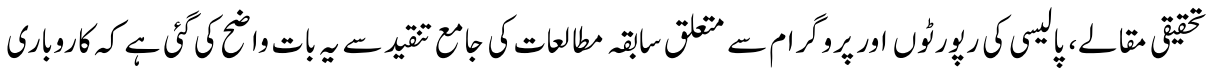

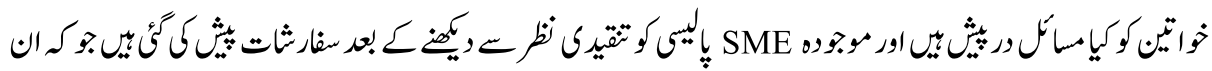

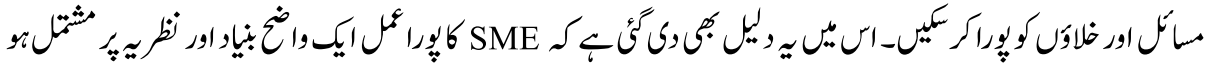

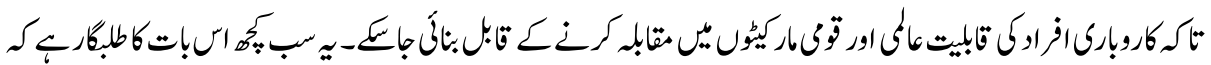

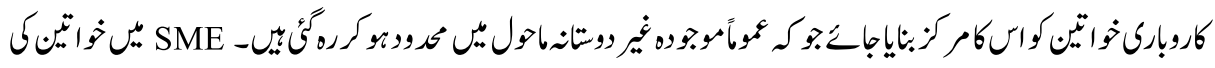

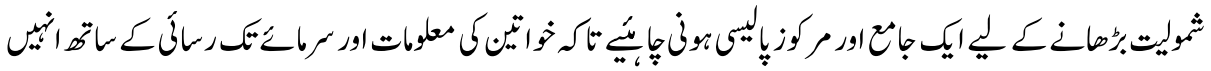

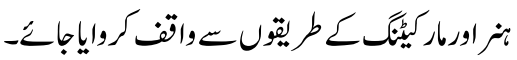

\section{Introduction}

Small and medium enterprises (SMEs) are often considered as panacea for generating labour-intensive employment opportunities needed to absorb expanding labour force, providing much needed flexibility and innovations in the economy as a whole, diversifying economic activities and making significant contribution to export and poverty alleviation (Afsar, 2007). SMEs provide vital linkages to larger enterprises making inroads to export market, and form part of the core business activities in both rural and urban areas. They also cater to the needs and demands of the medium and low income-earning groups. Existing estimates suggest that in Bangladesh SMEs together with micro-industries absorb 44 per cent of labour force, generate 50 per cent value addition in manufacturing sector and contribute 5 per cent to GDP (GOB, 2007; Bakht, 2006; World Bank, 2006; Amjad, 2005). Because of their smallness and labour-intensive nature, flexibility and low risk and low capital requirement these enterprises are more supportive of poverty reducing development strategies. The incidence of female employment tends to be higher in these enterprises, which increases their potential for poverty reduction. On the other hand, there is disproportionately high concentration of women in the low-productive, low-income generating micro-enterprises and subsequent low representation of women entrepreneurs in the SME sector due to some of the inherent problems of this sector compounded with gender based constraints.

Following the National Strategy for Accelerated Poverty Reduction (NSAPR) the major constrains faced by SMEs may be broadly divided into three categories (NSAPR 2005, Afsar, 2007). These are:

$>$ Policy-induced constraints emanating mainly from controls and regulatory measures e.g. unfavourable laws and regulations, cumbersome credit formalities including complicated project evaluation procedure, stringent collateral requirements based on ownership of fixed assets, and complicated tax structures, which often discourage investment in entrepreneurial activities;

$>$ Structural e.g. constrains relating to access to information, finance, infrastructure, skills and know-how, technology and markets result in SMEs' lower level of 
competitive advantage exacerbated by lack of R\&D and technological innovations and insufficient human resource development.

$>$ Constraints relating to poor governance and weak public service delivery Bakht (2006: 21) has rightly pointed out that with limited capital base of their own and little or no access to institutional financing and equity market, entrepreneurs often rely on inefficient financing services traditionally from informal sources, which eventually prove unsustainable not to talk of stimulating economic growth. The situation is particularly critical for women entrepreneurs who often do not own any fixed assets and have lesser access and priority to institutional credit as banks and other financial institutions generally prefer large enterprise clients because of the lower transaction costs, and greater availability of collateral. They are also constrained by limited access to family resources to which men have greater stake, little avenues for information and skills upgradation. In addition the prevailing gender unfriendly work environment and gender segregated work culture pose formidable barriers to women entrepreneurs of the country. Notwithstanding such barriers small and rural industries are often home-based and run by women entrepreneurs. Women entrepreneurs are also coming forward in export-oriented manufacturing in increasing numbers and contributing significantly to country's export earnings, generating employment opportunities to other men and women, providing assistance to larger businesses and specialised product and services, creating more competition and space for greater innovation for both domestic market and export.

Data from BBS show that in Bangladesh, only about 7.4 per cent of the establishments in manufacturing and services as of 2001-2003 are owned by women. This compares with about 20 per cent in India as of 2000 and that of nearly 39 per cent in the South-East Asian region ${ }^{1}$. Clearly it suggests the need for policy push to increase women's participation and enhance their capacity. Based on a thorough literature review including research and other policy as well as programme related documents, this paper aims to focus on the major constraints faced by women entrepreneurs; particularly those related to their capability building and suggest appropriate policy measures to address those gaps and challenges from a review of the existing SME policies. It is organised into three sections. The first one provides an overview of the SME sector, its characteristics and dynamics, types of activities performed in this sector, and its relative strength vis-à-vis other sectors in terms of employment generation. Section two analyses the existing policy, institutions and government support services and schemes geared to encourage the women entrepreneurs in SME sector. This is followed by gaps and constraints women entrepreneurs face, illustrations of some good practices and policy recommendations.

\section{Small and Medium Enterprise - An Overview}

In 2001/2003, there were about 78,400 small and medium enterprises (SMEs) in Bangladesh excluding those in public administration and defense. ${ }^{2}$ Small and medium scale establishments constitute 93 per cent of all establishments having between 10 and 
99 employees generating employment for some four million workers. Three-fifths of these establishments are located in urban areas accounting for three-quarters of employment of the SME sector, with rural areas accounting for the rest. SMEs absorb the bulk of the labour force of the non-agricultural sector. The dominant category among the micro enterprises is wholesale and retail trade whereas manufacturing oriented SMEs assume greater importance in employment generation accounting for nearly 36 per cent and 46 per cent of the employment generated by small and medium enterprises respectively (Bakht, 2006). Whether manufacturing, trade or services SMEs are predominantly run by private sectors. SMEs make a valuable contribution to the industrial value addition of the economy. Note that most of the value added originates from only a few industries e.g. food and beverages, jewellery and gems, leather and leather products, jute and jute products, textiles, furniture, wood products, paper products, garment accessories, handicrafts, etc (Dhungana, 2003).

In Bangladesh there is a fairly large number of SMEs in the apparel export industry that mainly performs sub-contracting jobs for the larger enterprises. A large part of the packaging industries also belong to the SME category. Interestingly, the paper products industry experienced 12 per cent annual compound growth during 1986 and 2002 (Bakht, 2006). Trade liberalisation in the 1990s eased access to imported inputs and thus facilitated the growth of SMEs in plastic, footwear, rubber products, chemicals, printings etc. Since trade restrictions usually put a greater burden on the SMEs compared to their large-scale counterparts, reforms in trade policy brought about quick supply response from the SMEs.

In the absence of gender-disaggregated data it is difficult to provide women's involvement in these different sectors. From different micro-level studies it may be said that women entrepreneurs largely concentrate in small and retail trading e.g. handicrafts, boutique, poultry, hatchery, nursery and agro-based industries, etc. manufacturing and a few services sectors. Government's initiatives to facilitate women entrepreneurs are often ad hoc in nature lacking in-built system of monitoring, follow-up and capability development focus. However, with the creation of a Small and Medium Enterprise (SME) Fund, the new SME Policy, 2005 and NSAPR's strategic goal to Promote SMEs and Women Entrepreneurship Development, it may be expected that addressing capability issues for SME development, particularly for women entrepreneurs will get priority as a policy agenda.

\section{Existing Policies and Institutions for SME}

The SME Policy Strategies developed under the Industrial Policy, 2005 by the government identified the "boosters" industries and proposed restructuring some of the existing institutions to provide useful training to the SME entrepreneurs. ${ }^{3}$ These are: 
- Bangladesh Small and Cottage Industries Corporation (BSCIC)

- Small and Cottage Industries Training Institute (SCITI)

- Bangladesh Institute of Management (BIM)

- Bangladesh Industrial Technical Assistance Center (BITAC)

- National Productivity Organization (NPO)

However, the SME policy of the government of Bangladesh, 2005 does not have any specific objective to promote gender equality in the SME sector or to promote female entrepreneurs. Moreover, the selection criteria for SMEs that will get finance from the SME Fund are stringent and difficult to attain for the women entrepreneurs although they are given preference in innovative ventures. ${ }^{4}$ For example, the policy identifies the small and medium enterprises as eligible which, after meeting the size requirement shall have-

- Proven credentials as an entrepreneur (for example, membership in wellrecognised social occupational groupings, successful track record) with requisite presence and facilities on the ground.

- An above-average insiders' equity participation.

- Certifiable for professional specialization of top-management in relevant production skills.

- The stamp of approval from globally-recognized quality-assurance bodies (ISO 9001:2000, for example).

- High management commitment to innovation. Women entrepreneurs will be accorded preference, wherever appropriate, and other things being equal, smaller enterprises shall be given preference in terms of benefits from interventions by the government and civil society initiatives.

\section{The Small and Medium Enterprise (SME) Fund}

In 2003-04 the government instituted Small Enterprise Fund (SEF) which is now known as the SME fund and a Tk. 1000 million refinancing scheme for credit to SMEs was set up under the Bangladesh Bank. The amount was raised to Tk.2500 million in the budget 2004-05 and raised to Tk.6200 million in 2007. To encourage entrepreneurs to benefit from the Fund, the Ministry of Industry prepares Action Plan. The action plan for 200708 aims to mainstreaming gender in SME entrepreneurship with the help of the following measures:

- Finalisation of Gender Action Plan

- Formation of the General Body/Membership of the Women Entrepreneurs Forum

- Formation of the General Rules of the Women Entrepreneurs Forum

- Annual Conference of the Women Entrepreneurs Forum

- Women Entrepreneurs' Product Fair 2008

- Best Women Entrepreneurs Award 2007

- Publication of a Women Entrepreneurs Handbook 
In addition it aims to take some innovative projects which among others include Creating Women Entrepreneurs in Computer-Assisted Design Embroidery and Spawning Women Entrepreneurs in Data Communication Industries. ${ }^{5}$ However, one may raise question about the basis of project selection and in the absence of data on the implementation status it is difficult to comment on the level of its commitments. Moreover it is clear that none of these action plans reflect the needs of the women entrepreneurs, particularly in relation to enhancing their capability.

\section{A Few Good Initiatives by Government for Women Entrepreneurs' Capacity Building}

\section{A. Refinancing Scheme for Women}

By issuing a circular issued on the 7th February 2007 to all scheduled banks and financial institutions, the Bangladesh Bank made the following provisions in SME Fund refinancing scheme in order to improve access of the women entrepreneurs to institutional credit. This includes:

- At least 10 per cent loan from SME Fund must be disbursed among women in SMEs by Commercial Banks.

- Provision of collateral free loan up to Tk.1.5 million

- Refinancing/revolving facility against loan amounting between Tk.100,000 to Tk.5.0 million from SME Fund

- Interest rate should be limited to +5 per cent to encourage women entrepreneurs to invest in trade and productive ventures

It has also defined SME for the three dominant economic sectors - services, business and industry as follows:

- SMEs in services sector are defined with the help of investment up to Tk.50000 to Tk.3.0 million in addition to requisite land and building assets and number of employees not less than 30 .

- SMEs in trade sector are defined with the help of investment up to Tk.50000 to 5.0 million in addition to requisite land and building assets and the number of employees not less than 20.

- SMEs in industry sector are defined with the help of investment up to Tk. 50000 to 10.0 million and the number of employees not less than 60 .

Undoubtedly this is a landmark decision in the way of women's capacity building. From table 1 one may observe that six financial institutions including banks have disbursed and refinanced Tk.3.9 million to women entrepreneurs up to December 2007 under SME fund following Bangladesh Bank's circular. If one compares it to the total amount of the SME Fund which is Tk.6200 million it would appear highly insignificant (.06 per cent). However, note that a number of other prominent and enlisted banks including BRAC 
bank are not included here. The role of BRAC bank deserves special attention as the largest disburser of SME fund and for establishing SME cell for women entrepreneurs and having around a quarter of women borrowers. Bakht (2006) noted that Brac bank alone disbursed 32 per cent of these loans while the other four institutions together accounted 38 per cent of the disbursement.

Moreover it is not only a matter of poor disbursement but also lack of information. Anecdotal evidence suggests that many women entrepreneurs and even service providers are not yet been aware of the Bangladesh Bank circular and the cell. ${ }^{6}$ Moreover some caveats still remain. One such gaps relates to interest rate as the BB circular did not specify a ceiling - in other words $+5 \%$ (maximum) interest rate could imply anything. Secondly, from Table 1 one may also find that most of the funds were disbursed for small and medium term but no fund has been disbursed for long-term re-financing schemes.

Table 1

Refinance Scheme of Women Entrepreneurs in Small Enterprise Sector, December 31, 2007

\begin{tabular}{|c|c|c|c|c|c|c|c|c|}
\hline \multirow{3}{*}{$\begin{array}{c}\text { Bank/Financial } \\
\text { Institutions }\end{array}$} & \multirow{3}{*}{$\begin{array}{l}\text { No. of } \\
\text { Loan } \\
\text { cases }\end{array}$} & \multicolumn{6}{|c|}{ Amount of Re-finance (in million Taka) } & \multirow{3}{*}{ Comment } \\
\hline & & \multicolumn{2}{|c|}{ Duration } & \multicolumn{4}{|c|}{ Purpose } & \\
\hline & & $\begin{array}{l}\text { Short } \\
\text { term }\end{array}$ & $\begin{array}{l}\text { Mid } \\
\text { term }\end{array}$ & Industry & Business & Service & Total & \\
\hline United leasing & 2 & 0.35 & - & 0.35 & - & - & 0.35 & $\begin{array}{c}\text { Refinanced } \\
\text { in } 31 / 10 / 7\end{array}$ \\
\hline $\begin{array}{l}\text { Phoenix } \\
\text { Finance }\end{array}$ & 1 & 0.5 & - & - & 0.5 & - & 0.5 & $\begin{array}{c}\text { Refinanced } \\
\text { in } 31 / 10 / 7\end{array}$ \\
\hline $\begin{array}{l}\text { Oman } \\
\text { Bangladesh } \\
\text { leasing }\end{array}$ & 2 & - & 1.28 & - & 1.28 & - & 1.28 & $\begin{array}{l}\text { Refinanced } \\
\text { in } 15 / 11 / 07\end{array}$ \\
\hline $\begin{array}{l}\text { Mercantile } \\
\text { Bank Ltd. }\end{array}$ & 2 & - & 0.8 & - & 0.8 & - & 0.8 & $\begin{array}{c}\text { Awaits } \\
\text { Ministry's } \\
\text { approval }\end{array}$ \\
\hline $\begin{array}{l}\text { Premiere Bank } \\
\text { Ltd. }\end{array}$ & 1 & 1 & - & - & - & 1 & 1 & $\begin{array}{c}\text { Refinanced } \\
\text { in } 5 / 12 / 7\end{array}$ \\
\hline Total & 8 & 1.85 & 2.08 & - & 0.35 & 3.58 & 3.93 & \\
\hline
\end{tabular}

* Source: Bangladesh Bank, Agricultural Loan and Special Programmes Division

\section{B. SME Cell and Outreach Centres}

According to the NSAPR the actions taken/underway to develop women entrepreneurship in the SME sector is as follows:

- Providing training and credit for women for SME scale business

- Business incubation, business center by women's trade bodies

- Set up stalls and facilities for women traders in trade fair 
- Small and medium entrepreneurship in non-traditional business

- Make women entrepreneurship development and support a part of all extension programs

From the Annual Development Programme (ADP) 2007-08 some support projects can be identified which are catering to the development of women entrepreneurs i.e. 'Promotion of Women Entrepreneurs for Economic Empowerment' under Jatiyo Mohila Sangstha (JMS) and establishment of three new vocational training institutions for women.

Last year the ministry of Industry, particularly SME cell under this ministry took some notable initiatives for improving the plight of business women which include organizing training for women SMEs, launching SME web portal, establishment of SME Foundations and women SME forum as a national network for women.

Anecdotal evidence suggests that till now the SME Cell of the Ministry made the following progress with regard to training and other activities under the project named 'Strategic support to SME Sector Training and Capacity Building project (SMESDP) with ADB fund: ${ }^{7}$

- A total of 9000 SME received various training, of them, 48 per cent were female.

- $32 \mathrm{SME}$ outreach centre out of 62 (as per plan) was established and 3 of those centres are exclusively meant for women entrepreneurs. SME established at BWCCI, women entrepreneurs association of Bangladesh and Chittagong women Chamber.

- SME foundation organized two women SME conference at the national level attended by women entrepreneurs from different districts

- SME web portal incorporating various data on women SME has been launched (www.smef.org.bd )

With a network of 1000 member entrepreneurs, Bangladesh Women's Chamber of Commerce and Industry (BWCCI) is also working relentlessly to voice the concerns of women entrepreneurs to protect their interest and enhance their capability. No doubt these are important steps toward capacity building of women entrepreneurs but without any clear idea about types of activities of these institutions and contents of training and mechanisms for regular monitoring and feedback, it is difficult to comment on the impacts of these institutions on the capability development of the entrepreneurs. 


\section{Major Constraints and Policy Imperatives}

\section{- Constraints Faced by Women Entrepreneurs ${ }^{8}$}

\section{A. Lack of Information and Problems in Accessing Inputs and Services}

- Many women entrepreneurs are not aware of the necessity of having trade license and the way to obtain it, and a large number also face administrative difficulties to obtain it. This hampers their operation i.e. getting bank loans.

- Women entrepreneurs often lack specific knowledge about tax and VAT. Many do not have a TIN number which is an obstacle to get institutional loans.

- Complex and cumbersome process of getting institutional loan constitutes the most formidable barriers for women entrepreneurs managing enterprises. Moreover, the banks demand collateral which many women SMEs are unable to provide.

- A review of women SMEs by the ministry of Women and Children's Affairs (MoWCA) showed that only 13 per cent of the respondents obtained loan from institutional sources and in 20 per cent cases the amount was less than Tk.50000.

- Many commercial banks require signature of father or husband as a guarantor to provide loans which keeps women dependant on their male 'guardians'.

- Most of the women entrepreneurs do not have access to information related to marketing procedure and no space is earmarked for them in the Municipal or Haats and Bazaars to display their products. Due to the lack of market linkages many a times the women SMEs sell their products at a low price.

- Women entrepreneur do not have substantial safety net to support them through the risks of business; they do not have fall-back measures in case of failures or accidents.

- Women unfriendly governance in all relevant offices makes it difficult to work properly for the women entrepreneurs.

\section{B. Training and Skill Development}

- The scope for training of the women entrepreneurs at local level is very limited and there is no link between skill development and credit disbursement which hampers the transition of a trained woman into a SME owner.

- The MoWCA study shows that only 25 per cent of the women entrepreneurs have some training of which only 14 per cent have training on management, finishing, marketing and quality development.

- They do not have access to information needed to set up a SME and run it successfully, neither do they have a support network. 


\section{Policy Imperatives}

Whether manufacturing, trade and/or services including exporting temporary service providers Bangladesh like many LDCs lack technological capability for keeping pace with competitiveness and technological innovation. For better or for worse, globalization is here to stay albeit the playing field remains highly uneven. Domestic institutions and policies must create level-playing grounds to ensure efficiency and greater productivity while minimizing the risks of marginalisation and negative externalities. There is no substitute for capacity building through education, science and technological diffusion and investing in R and D; access to necessary services and institutions.

The whole process of SME development should have a clear structure and a vision for enhancing capability of the entrepreneurs to compete in the global and domestic markets which demand special focus on women entrepreneurs who are often marginalized in the existing women unfriendly environment. To attain this, a broad and comprehensive focus on information and capital accessibility, skill development and marketing linkage is essential. It is important to emphasize on both vertical and horizontal mobility of the women entrepreneurs. To say that women are lagging behind because of patriarchal social structure and economy is not enough anymore. Women entrepreneurs should be given priority in developing SMEs as it helps alleviating poverty, generating employment opportunity, and boost the trade and export of the country and geared toward a sustainable development.

It may be worthwhile to take a note of the four-point formula proposed by the former Chief Adviser, Dr. Fakhruddin Ahmed with a special focus on female entrepreneurs for flourishing small and medium enterprises in the country. ${ }^{9}$ These are:

- Reduce the existing rates of bank interest

- Set up SME unit or desk in commercial banks and financial institutions

- Make loan-disbursement procedure quicker and simpler and incorporate business strategy for providing SME loan

- Create woman-friendly environment in banks and financial institutions, and fix SME-friendly tax, duty and VAT structure.

His suggestions must be given high priority by banking, taxation and other financial institutions. In addition the following recommendations demand attention as policy agenda with focus on capacity building of women entrepreneurs for flourishing small and medium enterprises in the country.

\section{Recommendation}

Based on the constraints faced by women entrepreneurs policies must be streamlined in four major areas and these are - regulatory and administrative; monitoring and implementation, capacity development and women friendly services. 


\section{A. Regulatory and Administrative}

- City corporations, municipalities and local government should ease the regulatory processes regarding trade license for women.

- Government should give special tariff facilities to women entrepreneurs

- Provide administrative supports and services to women entrepreneurs for information dissemination related to taxation, licensing and VAT and simplify those regulations

- Different ministries working on the development of women entrepreneurs should collaborate under a coherent plan of action.

- Increase public-private partnership and Government-NGO collaboration to increase the coverage of credit and training programme

\section{B. Monitoring and Implementation of Existing Policies}

- Bangladesh Bank should fix up a target for each bank to provide loan for women SMEs and form a monitoring team to monitor the implementation of the Bank circular.

- Ensure proper dissemination of information including government circulars that may benefit the women entrepreneurs

- Establish and SME cell in each private bank and ease the process of getting loans and opening accounts for women.

- The opportunities to obtain institutional loans should be easily accessible in rural areas as well as the urban areas.

- Generating gender disaggregated data on SME sector is necessary to monitor progress of the women SMEs.

- Increase allocation for women SME development in the national budget

\section{Capacity Development}

- Establishment of a women entrepreneurship academy for the capability development of the women SME

- Set up specially designed comprehensive training programmes for women SME that address skills and product development as well as marketing, networking, managerial and administrative issues. Training needs in specific skills for various trades have been identified in past studies of the Ministry of Industry. These include advance level courses and basic courses in several industry groups where women entrepreneurs are involved. Most significant industry groups are in poultry, hatchery, nursery and agro-based industries. Advance level training in these fields can be organized after completion of basic trainings and after getting some satisfactory level of experience in that particular field. ${ }^{10}$ 
- Special capacity building programmes for the women SMEs on finance, business management, documentation system, accounting etc. should be developed.

- Women SMEs should be provided with training and easy access to IT facilities even in the rural areas.

- Credit facilities and insurance to cushion against accidents, injuries, business loss and other crisis situation

- A strong network of women entrepreneurs and organizations should be developed and scheme should be designed to link women entrepreneurs with their counterparts in the region and international networks

- Credit should be provided to groups of women entrepreneurs without collateral and the interest rates should be lowered for them between 5 and 10\%.

\section{Women Friendly Services}

- City corporations and Municipalities should have special quota to reserve space for women entrepreneurs in the markets under them.

- Media should play a vital role to disseminate necessary information and facilities regarding SMEs for women and other marginalized groups

- Banks should give special facilities to women entrepreneurs and provide support to make the government scheme work for them

- Set up separate women entrepreneurs support cell in various organizations e.g. BSCIC, EPB, BSB, etc. and all chambers of commerce

- Provide special support to women entrepreneurs who are involved in exportoriented activities for promoting marketing of their products in overseas markets

- Organize trade fairs, especially for women entrepreneurs in those countries where there is sizeable demand of Bangladeshi goods

\section{End Notes:}

${ }^{1}$ Naeem Chowdhury, "Creating a Gender Action Plan for Women Entrepreneurship: Stanching Financing, Marketing, Technology, and Mindset Gaps". Paper presented in the First National SME Women Entrepreneurs Conference, August 8, 2006, Dhaka.

${ }^{2}$ With partial funding from the Asian Development Bank-assisted Small \& Medium Enterprise Sector Development Programme (SMESDP), the Bangladesh Bureau of Statistics (BBS) is completing an updating of the number of SMEs as of 2005/2006.

3 These "booster" industries are -- Electronics and electricals; Software-development; Light engineering and metal-works; Agro-processing/agri-business/plantation agriculture/ specialist farming/tissue-culture;Leather-making and leather goods; Knitwear and ready-made garments; Plastics and other synthetics; Healthcare and 
diagnostics; Educational services; Pharmaceuticals/cosmetics/toiletries; and Designer, aesthetically challenging and personal wear and effects.

${ }^{4} \mathrm{SME}$ Fund is discussed in the next section.

${ }^{5}$ Additionally, the Ministry wants to undertake projects e.g. Towards Automation of the Renewal of Trade Licenses, conduct a study on Comparative Effect of Taxation of SMEs in china, India and Bangladesh; Building a next-generation Data-Communication Infrastructure for the SMEs in Bangladesh and Heat Treatment Facilities in Bangladesh.

${ }^{6}$ This is revealed during field work by FBWCCI.

${ }^{7}$ BWCCI staff members collected this information from the Ministry of Industry over telephone.

${ }^{8}$ Major constraints and recommendations are drawn from following reports and also from the analysis presented above - (i) BWCCI. Quarterly Progress Reports, PWEA project of BWCCI (phase-2) in cooperation with CIPE, Dhaka, December 2006-february 2007; September-November 2007 and June-August 2006; Rummana, Ruba. 'Budget Aspirations of Women Entrepreneurs in Bangladesh: An Interactive Discussion with Media', BWCCI Dhaka, 2006, and Shamim, M.U. 'Problems and Redressal of Women SME Development in Bangladesh: The opinions of Respective Stakeholders', BWCCI Dhaka, 2007.

${ }^{9}$ While inaugurating the daylong 2nd National Women SME Entrepreneurs Conference 2008, Chief Adviser Dr Fakhruddin Ahmed spelt out this four steps.

10 Report on Training Needs Assessment of Small and Medium Enterprise Sector Development Program (SMESD). Training Needs Assessment Committee, SME Cell, Ministry of Industries. 2005.

\section{References}

Afsar, R. (2007) Promoting Remittances Management in South Asia: Promoting Remittances and Small and Medium Enterprises Links In Bangladesh, A Paper Prepared for Nepal Rastra Bank Organized SAARCFINANCE Seminar on "Management of Workers' Remittances in SAARC Countries", May 9-11, 2007, Kathmandu, Nepal

Amjad, R. (2005) Remittances and Development in South Asia, South Asian Journal, 6 www.southasianmedia.net/Magazine/Journal/6 remittances.htp accessed on the 24th April, 2007) 
Bakht, Z. (2006) Development of SME Sector in Bangladesh, A paper prepared for Review of Bangladesh Development, Centre for Policy Dialogue, Dhaka

Government of the Peoples' Republic of Bangladesh (2007) Bangladesh Economic Review 2006, Economic Adviser's Wing, Finance Division, Ministry of Finance, Dhaka

Dr. Rita Afsar, Senior Research Fellow at Bangladesh Institute of Development Studies. 